\title{
Transformation and Multiple Choices in Suppliers of Public Services Xue-Ping $\operatorname{LIANG}^{1, \mathrm{a},{ }^{*}}$
}

${ }^{1}$ Economic College, TianJin University of Commerce, P. R. China, TianJin 300134

axp4169@sina.com

${ }^{*}$ Corresponding author

\section{Keywords: Public Services, Supplier, Commercial Supply, Voluntary Supply}

\begin{abstract}
The government is an authoritative supplier, private enterprise is a commercial supplier, and non-profit organization is a voluntary supplier. The suppliers of public services can change because of the influence of some constraint factors such as technical progress, transaction costs, path dependence, and so on. At present, as a single authoritative supplier, the government can't meet the diversified and multi-level public demand. Therefore, the government should guide nonprofit organizations and private enterprises to supply public services, construct the diversified suppliers pattern to guarantee the effective supply of public services.
\end{abstract}

\section{Introduction}

For a long time, the government is regarded as an authoritative supplier of public services. Due to some constraint factors such as monopoly supply, information incompleteness, bounded rationality, etc. the government is not the most effective supplier of public service. "Government failure" and the limitations of supply capacity cause the government's inadequate supply. With the development of technology, changes in the economic and social environment, it is possible for the private enterprises to supply public services efficiently through the market. In the 1960s, with the emergence of welfare state crisis, Demsetz(1970), Goldin(1979, Coase(1974), Schmidtz(1987)began to suspect the rationality which the government was the only supplier of public service, and demonstrated the possibility of commercial supply from the perspective of theory and experience. In the trend of public administration reform, influenced by new public management theory and the ideas of reinventing government and reengineering public sector, western countries introduced the competition mechanism to break government monopoly in the field of public service. As a result, private enterprises gradually were the important suppliers of public service. Because of the attribute of pure public goods, the private suppliers couldn't overcome the "free-riding" problem.

Under the influence of people's mutual communication, mutual psychological and Altruistic motives, many nonprofit organizations can voluntarily supply public service to meet the growing and diverse demand. Weisbrod (1974, 1986), Hansmann (1980), Salamon (1987) studied the comparative advantages of non-profit organizations in supplying public service. Since the 1990s, the nonprofit organizations play an active role in the fields of environmental protection, health and medical care, charity, education, public security, etc. voluntary supply of nonprofit organizations is the beneficial supplement in supplying public service, and shows the incomparable efficiency advantages.

In the critical period of economic and social transformation and the all-round development stage of constructing well-off society, the dual pressure (from institutional transition, economic and social transformation) leads to public demand for public services to grow increasingly. Because the supply mode of government monopoly can't meet the diversified and multi-level public demand, the 
contradiction between supply and demand of public service is obvious. The involvement in supply of nonprofit organizations and private enterprises can improve supply efficiency of public service to a certain extent, Therefore, how to select the suppliers has been a key problem affecting the supply efficiency of public service.

This article analyzes the transformation forms of public service suppliers, studies the constraint factors of affecting the supplier transformation based on the boundary conditions in supplying public service among the government, enterprises and non-profit organizations, puts forward the policy paths of perfecting supplier system of public service.

\section{The supplier transformation of public service and its constraint factors}

\section{The supplier transformation of public service}

\section{The transformation from the Enterprises to the government}

In the early stages of the western capitalist countries, the government's activities were limited the narrow range of "night watchman" in private economy, the fields of the private sectors' activities were very wide. The private enterprises supplied a lot of personal items, also provided some public services to a certain extent. The transformation process of the suppliers from the enterprises to the government was the process of the expansion of government's activities and the contraction of market activities in the field of supplying public service. In many classic textbook, the lighthouse is often regarded as the example of government 'supply rather than enterprise's supply, any private enterprise couldn't get profit in building or repairing the lighthouse (Muller, 1965; Samuelson, 2002). However, the history of building and management the lighthouse revealed that early British lighthouses were supplied by private sectors through the market. In the 1830s, the British parliament awarded the lighthouses to trinity house by law, Britain have no the private lighthouses except the local lighthouse by 1842 .

\section{The transformation from nonprofit organizations to the government}

With the development of society and economy, as the core part of the public sector, the governments' social responsibility drove them to do more, some public services supplied by nonprofit organizations were gradually provided by the government. For example, the firefighting service is widely regarded as a pure public goods, it should be supplied by the government. In fact, the early firefighting services were provided by the nonprofit organizations in American, in the middle of the 19th century, the governments in many cities began to provide firefighting services, and banned the nonprofit organizations from providing them, so the history about 200 years of the voluntary supply in firefighting service was over (McChesney,1986).In the history of American, environmental protection, family planning, charity, education were provided by nonprofit organizations, many of them were eventually provided by the governments.

\section{The transformation from the government to the Enterprises}

Since the 1960s, with the reform trend of public administrative in western developed countries, influenced by the ideas of reinventing government, reengineering public sector and the new public management theory, some functions of the governments began to shift to the private sectors. Many public services originally provided by the governments were gradually supplied by private enterprises. For example, the provision of public facilities was the main responsibility of the government (Smith, 1776). These public services play an irreplaceable role in creating good environment of production, business operation, investment and accelerating economic development. With the development of economy, private enterprises play more and more important roles in the investment of the infrastructure, and form the some important financing model such as BOT 
(build-operate-transfer), PPP (public-private-partnership), and so on.

\section{The transformation from the government to nonprofit organizations}

Being able to consciously respond to the diversified and multi-level public demand, the voluntary supply of nonprofit organizations can make up for the defects caused by "government failure" and "market failure". Nonprofit organizations play the indispensable role in eliminating poverty, rural education, health care, disaster relief, ecological environment protection and the provision of social services, etc. it is the embodiment of an efficiency advantages which the suppliers are from the government nonprofit organizations. For example, social welfare and social security has always been supplied by the government, with the continuous development of nonprofit organizations, nonprofit organizations become the important supplier of residents' social welfare and social security.

\section{The main factors influencing the transformation of public service supplier}

The change of the suppliers of public service is not random; it is influenced by a series of constraint factors.

\section{The variability of public service's attributes}

For the attribute of public services, non-exclusiveness of public service and their difference is the direct constraint factors, non-competitiveness and their difference is the indirect constraint factors.

Non-exclusiveness and non-competitiveness led to the market failure of the enterprise supply. The typical public service is only suitable to be supplied by the government. Except the typical public service, the majority of public services belong to quasi-public goods with the degree difference of non-exclusiveness and non-competitiveness. This creates the conditions for the supplier transformation of public services. Some public services originally supplied by the government can be provided by private enterprise through the market if the public services have certain exclusiveness or the relatively low exclusive cost. Some public services originally supplied by private enterprise can be provided by the government if they have significant positive externalities and the market can't internalize the external benefit. Natural monopoly industry which is lack of the competitiveness can be supplied by the government directly, also can be supplied by the enterprise under the government's regulation.

\section{Technological progress}

Technology level is the premise of the supplier's transformation of public service, because the technology progress can affect the non-exclusiveness degree of public service, thus influence the supplier's transformation of public service.

Technology's effects on the suppliers of public service mainly displays in: (1) the improvement of exclusive technology effectively prevents the behavior of "free rider", and accurately measures the income and cost of consumption in public service, so it is possible for private enterprises to supply public services; (2) constantly update of technology reduces the investment cost of natural monopoly, this makes it is possible for the private enterprises to supply public services with the characteristics of natural monopoly; (3) the clarity of the property rights makes consumers' consumption benefits consistent with their payment costs, thus creates the necessary economic or institutional incentive, and limits the constraint conditions in private supply of public services.

\section{The transaction costs}

In the process of supply in public services, there are lots of the transaction costs of public services, no matter these public services are supplied by the government, or by the private enterprises, or by nonprofit organizations.

Because of information asymmetry in public demand preference, information incomplete 
between the suppliers, the emergence of opportunistic behavior, it leads to the transaction costs before the supply of public service (mainly the negotiation costs and the contracting costs). There are lots of transaction costs after the supply of public service, such as the price-making costs (shown as the tax and fee), the financing costs, the operating costs (shown as rent-seeking, low efficiency, supply failures, etc.), the coordination costs between the suppliers, the supervision and regulation cost, etc. The supply way of the government can save the costs of price-making, financing, supervision and regulation, with the expansion of supply scale of public services, the costs of negotiation, contracting and operating increase because of the information asymmetry, opportunistic behavior and asset specificity. The supply way of the enterprises can save the costs about negotiation, contracting and operating, with the expansion of public demand, the costs in price-making, coordination, supervision and regulation increase significantly. The supply way of nonprofit organizations can save the costs about negotiation, contracting, price-making and coordination, but inevitably produces the costs of financing, operating, supervision and regulation.

In general, considering the given conditions of the production cost and technology level of supply for public service, the supplier transformation of public services is dependent on the transaction costs in the supply process of public service. The supply of public services should be provided by the supplier with minimum transaction cost or saving more transaction costs.

\section{The government's preference in goals of equity and efficiency}

In terms of public services, the supply fairness of public service is reflected in: all social members (regardless of income level) have equal rights, equal opportunity, fair results in getting public services. To achieve the goals of the fairness, the supply of public services relies on the government. However, the supply of public services needs to consider efficiency goals, especially in the supply field of quasi public service. The supplier transformation of quasi public service is dependent on the comparison of costs and benefits. It is possible for the enterprises to provide public services if the supplier can obtain more benefit than the costs. The choice between the fairness goals and the efficiency goals affects the supplier choice of public service. If the government prefers the fairness goals to the efficiency goals, the supplier may be the government. If the government prefers the efficiency goals to the fairness goals, the supplier may be the private enterprises. When the government pays equal attention to the efficiency goals and the fairness goals, the supplier may be one of the government, the private enterprises and non-profit organizations.

\section{The influence of path dependence}

The concept of path dependence originally derives from people's understanding the positive feedback mechanism of open system in the field of natural science. The positive feedback mechanism is similar to "inertia" in physics (a kind of self-reinforcing mechanism about the system).

From the perspective of path dependence, the transformation direction of the suppliers is not random, there is the path dependence. If the initial choice of the suppliers has accumulated huge interests for the consumers and providers of public services, the current change of the suppliers is not the pareto optimality because the transformation about the supplier can't increase the welfare level of the vested interest groups, so there is huge resistance in changing the suppliers of public services. For example, the infrastructure with the property of natural monopoly is provided by the government at low price or limited price in order to ensure the higher benefits for the consumer. With the development of market economy and the progress of technology, the supply of private enterprise can improve the supply efficiency of public services, but the transformation of the suppliers should be considered the path dependence of government supply. 


\section{The policies to perfect the system of the suppliers in China's transitional period}

\section{Introducing the diversified supply modes to produce the synergy of different suppliers}

At present, the public demand in public services is increasingly growing and tends to be diversified. The government's monopoly supply has been difficult to meet public demand for public services. For the diversified and multi-level public demand, the government needn't supply comprehensively, should introduce the private enterprises and nonprofit organization into the supply field of public service with the purpose of forming the diversified supply pattern. This supply pattern can ease fiscal pressure of the government, and improve the level of public welfare.

Strengthening the relationship governance between the suppliers and dividing the supply area of public services reasonably

\section{Strengthening the relationship governance between the suppliers}

In spite of the difference in supply goals of public services for the government, enterprises and non-profit organizations, but there is the relations of cooperation and competition among the suppliers. The government should develop the partnerships with private enterprises and non-profit organizations in the collaborative supply of the public services. This increases the quantity of public services and improves the quality of public services, also improves the supply efficiency of public services. For example, Wuthnow (1991) used a classic example to illustrate the close relations of cooperation which different suppliers coped with food problems of the old in the city, the government bought the food, the enterprises produced it, nonprofit organization send it to the old.

The government strengthens the competition and cooperation with the private enterprises and non-profit organizations so as to correct the supply failure of public service. The government introduces the private enterprises and non-profit organizations through the incentives mechanism, thus this is helpful to reduce the efficiency losses of the supply of public services. On the specific institutional arrangements, the government promotes the commercial supply of public service by government procurement, franchise, common shares and economic aid, and encourages the voluntary supply by the way of financial assistance and preferential policies.

\section{Dividing the supply area of public services reasonably}

The function domain of the different suppliers is different, so the government needs to divide the supply areas reasonably. The government provides the basic public services such as public health, basic education, ecological environment protection, basic science research, administrative services, etc. The private enterprises provide welfare-type public services and quasi public services such as pension insurance, medical services, transportation services, public utilities services, public cultural services, etc. Nonprofit organizations provide small, scattered public services or public services of the community such as poverty relief, environmental protection, health and care, public education, technology promotion, etc.

\section{Strengthening the leading role of government in the diversified suppliers system}

\section{Defining the property rights of public services through making economic incentives}

Due to the investment specificity of public service, it is critical in the definition and effective protection of property right. The government should perfect the relevant institutional arrangement of property rights, clearly define property rights and guarantee the investment income claims about public service. Only in this way can the government provide enough economic incentive to other suppliers. The World Bank development report in 1995 also pointed out that the incentive of the arrangement in private property rights is better than that of public property right.

Perfecting the supply system of public service through making institutional incentives 
Because quasi public services has characteristics with large scale of the investment, long period of payback, and low profits, the government should encourage private enterprises to participate in the supply of public services through fiscal subsidies, tax cuts and tax rebates, etc. The government should stimulate nonprofit organization to supply public services through lowering admittance threshold and tax preferential policies. The government should reduce the limit of approval, and give more tax exemption treatment for non-profit organizations.

\section{Strengthening the institutional constraints to regulate the supply behavior of private enterprises and non-profit organizations}

In order to prevent the monopoly supply of public services and guide the enterprise investment, the government should perfect the market access system, the pricing system, the information disclosure system, and investment planning system. The government should support and guide the non-profit organizations to make full use of their own efficiency advantage to improve the supply of public services and eliminate the problems of "voluntary failure" through funding support, information communication, organization supervision and other measure.

\section{Conclusion}

In fact, the suppliers of public service are not invariable, and they can change with the variation of time, technical conditions, demand conditions and the level of system design. The government, the enterprises and non-profit organizations involves in the supply of public services, and forms a diversified supply system. So it can ensure the effective supply in public services if the different suppliers play their respective advantages and reach the supply equilibrium in the field of public service.

\section{Reference}

[1]R. H. Coase, The lighthouse in economics, Journal of Law and Economics, Vol, 17, No.2, pp.357-376,(1974).

[2]E. Williamson, The Economic Institutions of Capitalism: Firms, Markets, Relational Contraction, New York, Free Press, 1985.

[3]Chen yan,. Fairness and Efficiency, China social sciences press, 2007, pp.25-73.

[4]D. C. North, Institutions, institutional change and economic performance, Shanghai San Lian publishing company, Shanghai people's publishing house, 1994, pp.132.

[5]Fan Li-ming and Shi Shao-bin, The supply mechanism of Public goods: the boundary changes and influence factors, Journal of Contemporary Economic Science, Vol.1, (2006).

[6]Fan Li-ming. Analysis on market supply and voluntary supply of public goods in China, Shanghai people's publishing house, Shanghai San Lian publishing company, 2005.

[7] Chu Yong-sheng and Zhang Xian-chang, Study on the supply of public goods from dynamic perspective, Journal of Modern Economic Research, Vol, 3, pp.19-21, (2005). 